\title{
Managing Public Health Risks Using Air Monitoring at a Former Manufactured Gas Plant Site
}

\author{
Robin De Hate1,2*, Brian Skelly², Marie Bourgeois', Ushang Desai', Giffe T. Johnson1, \\ Raymond D. Harbison ${ }^{1}$ \\ ${ }^{1}$ Center for Environmental/Occupational Risk Analysis and Management, College of Public Health, University of \\ South Florida, Tampa, USA \\ ${ }^{2}$ GEI Consultants, Inc., Valrico, USA \\ Email: ${ }^{*}$ rdehate@geiconsultants.com
}

Received 13 September 2014; revised 9 October 2014; accepted 2 November 2014

Copyright $@ 2014$ by authors and Scientific Research Publishing Inc.

This work is licensed under the Creative Commons Attribution International License (CC BY).

http://creativecommons.org/licenses/by/4.0/

(c) (i) Open Access

\begin{abstract}
Monitoring emissions from a former Manufactured Gas Plant (MGP) site during remediation was used to manage risks associated with inhalation of Volatile Organic Compounds (VOCs) and contaminated particulates acting as an exposure conduit for Polycyclic Aromatic Hydrocarbons (PAHs) and heavy metals. This risk management case study presents a USEPA-approved air monitoring program implemented to manage public health risks during remediation at a former MGP site located in the southeast United States. Risk-based Acceptable Air Concentrations (AACs) were developed and a sampling regimen established to monitor potential emissions to maintain contaminant concentrations below the AACs. The exposure duration used was based on a twelve-month project duration and an exposure time of 24 hours per day; equations, toxicity values and sources were based on USEPA's Regional Screening Levels. A total 535 twenty-four hour time weighted samples (269 VOC samples and 266 PAH samples) were collected over the project duration. Only minor levels of VOCs and PAHs were detected and no results were above the AACs. These timeweighted averages demonstrate that the real-time air monitoring and control measures implemented at the site effectively maintained concentrations below the AACs and were protective of public health.
\end{abstract}

Keywords

Risk Management, Remediation, Manufactured Gas Plant, Exposure Monitoring, Public Health

${ }^{*}$ Corresponding author.

How to cite this paper: De Hate, R., et al. (2014) Managing Public Health Risks Using Air Monitoring at a Former Manufactured Gas Plant Site. Journal of Environmental Protection, 5, 1400-1405. http://dx.doi.org/10.4236/jep.2014.514133 


\section{Introduction}

The purpose of the Air Monitoring Plan (AMP) at the former Gasification Plant site was to provide early detection in the field of short-term emissions of site related chemicals. The early detection of emissions and associated contingency measures was intended to expedite any necessary mitigation measures, and to reduce the potential for the community to be exposed to constituents at levels above accepted regulatory limits and recommended guidelines [1].

The target chemicals for the air sampling and monitoring program were based on the previous environmental investigations and the in situ stabilization/solidification pilot test performed at the site in August and September, 2009 [2]. These constituents were associated with typical Manufactured Gasification Plant (MGP) operations and included selected volatile organic compounds (VOCs) and polycyclic aromatic hydrocarbons (PAHs). Air monitoring for this site was conducted during remediation activities performed from December 14, 2009 through January 31, 2011 and pre-remediation baseline air monitoring was conducted from December 4 through 13, 2009 [2].

Twenty-four-hour confirmatory air sampling was conducted and laboratory measured concentrations of constituents were derived for comparison to the acceptable air concentrations (AACs) to evaluate the continuous monitoring system. The AACs were developed to ensure protection of human health with an ample margin of safety [3] [4].

\section{Methods}

\subsection{Air Monitoring Plan (AMP)}

The AMP consisted of ten real-time air monitoring stations (AMS 1 - 10) along the site perimeter and one meteorological station for determining and recording wind direction [5]-[7]. The number and locations of these stations were based on expected work activity and proximity to potential adjacent receptors. Six AMS were placed along the perimeter where the potential emission was the greatest, four AMS were placed at cloud branch creek at locations set up to capture potential emission from the sediment remediation [5]-[7]. Each real time AMS recorded TVOC and PM10 concentration along the site perimeter. The AMP was supplemented with handheld air monitoring instruments for TVOC and dust at perimeter locations, conducted as needed during remedial activities. Time weighted 24-hour average VOC and PAH samples were collected once per week to show that realtime AMS were effective in measuring concentrations of the target VOCs. The samples were collected in 6-liter summa vacuum canisters and high volume PUF cartridges and submitted for laboratory analysis by USEPA methods TO-15 and TO-13A at AIR Toxics Ltd., CA, a USEPA approved laboratory [5]-[7].

\subsection{Acceptable Ambient Concentration (AAC) and Action Level Development}

Many different volatile chemicals are present in MGP wastes, but on-site air management decisions are usually based on the monitoring of representative target compounds based both on the potential risk imparted by a compound's prevalence and toxicity, as well as the analytical ability to detect these compounds. The odor threshold of particular VOCs also factors into their inclusion as a sentinel compound, since odors around MGP excavations speaks directly to public risk perception surrounding the remediation work.

The target analytes for the air sampling and monitoring program were based upon the previous environmental investigations and a pilot test performed at the site in August and September, 2009. The constituents are associated with typical MGP operations and include selected VOCs and PAHs.

The early detection of emissions and associated contingency measures is intended to expedite any necessary mitigation measures, and to reduce the potential for the community to be exposed to constituents at levels above accepted regulatory limits and recommended guidelines.

Acceptable Ambient Concentrations (AACs) were calculated to be adequate to protect human health with an ample margin of safety, especially since ambient air concentrations were compared to the AACs at the fence line, which was approximately 50 to 100 feet from the nearest receptor. To provide confidence emissions from operations would achieve the AACs; the Action Levels were developed. Although these 15-minute-time-weighted average Action Levels were derived from acute toxicity values, field experience at similar sites, demonstrated that emission control procedures based on these Action Levels was protective of human health over the duration of the project. 
Site specific AACs were calculated using target cancer risk (TR) value of $1 \times 10^{-4}$ for carcinogens and a target hazard quotient (THQ) of 1 for non-carcinogens. The exposure duration used was based on conservative 12month project duration (365 days) for the active remedial operations including excavation and in-situ stabilization/solidification (ISS). The exposure time was based on 24 hours per day, which is consistent with the proposed 24-hour sample collection period. Equations, toxicity values and sources were based on USEPA's Regional Screening Levels web site [8].

The AAC for benzene was based on carcinogenic effects using the inhalation unit risk (IUR) from the USEPA's Integrated Risk Information System (IRIS) database. The AACs for toluene, ethylbenzene, and xylenes were based on non-carcinogenic effects using the chronic Reference Concentration (RfC) from the IRIS database. The AACs for the carcinogenic PAHs was based on carcinogenic effects using the IUR from California EPA, since the IRIS has not established IURs for PAHS.

The mutagenic equation was not used for the carcinogenic effects. The mutagenic equation applies for longterm exposure durations (multiple years), and therefore it was not considered appropriate for the project duration of less than one year. The AAC for PM10 is the National Ambient Air Quality Standard (NAAQS) for PM10 and was used as a surrogate for both the PAHs and heavy metals.

The USEPA Region 4 Technical Support Section recommended a naphthalene air concentration of $9 \mathrm{mg} / \mathrm{m}^{3}$ $(1700 \mathrm{ppb})$ as health protective for the specific short term exposure scenario at the site. There are a few federal health based levels readily available for Naphthalene in air. The following is a description of the methodology used by USEPA Region 4 Technical Support Section to establish this AAC.

The Occupational Safety and Health Administration (OSHA) Time-Weighted Average for occupational exposure (TWA) $=10 \mathrm{ppm}$ or about $50 \mathrm{mg} / \mathrm{m}^{3}$. (NIOSH 2005) This value is meant to protect a worker exposed for $8 \mathrm{hrs} / \mathrm{d}$, chronic exposure duration. It is based on no effects (irritation of the eye, skin, nose; abdominal pain, etc.), as observed by the exposed person. It does not appear to be based on the more sensitive, subtle cellular level effects which form the basis for the EPA RfC and ATSDR MRL.

EPA chronic exposure Reference Concentration (RfC) for Naphthalene in air $=0.003 \mathrm{mg} / \mathrm{m}^{3}$. (IRIS 2007) EPA has no verified Inhalation RfC available for less than chronic exposure. This value is derived from the lowest effect level in a chronic inhalation exposure mouse study which converts to a human equivalent concentration of $9 \mathrm{mg} / \mathrm{m}^{3}$. The RfC is derived by applying a total uncertainty factor of 3000 . This concentration is meant to be protective for all human receptors including infants and children exposed daily for a lifetime duration. This value is more protective than needed for our interim remediation scenario as we will not have: 1) infants, children, or women of child-bearing age exposed; or 2) exposure extending beyond 6 months duration.

Agency for Toxic Substances and Disease Registry (ATSDR) Minimal Risk Level (MRL) for chronic inhalation of Naphthalene $=0.0007 \mathrm{ppm}$ or about $0.003 \mathrm{mg} / \mathrm{m}^{3}$. (ATSDR 2005) ATSDR has no recommended Inhalation MRL available for less than chronic exposure. The value is based on the same toxicological study as the EPA RfC value, so the same comments would apply.

Starting from the OSHA value and converting from an exposure time of $8 \mathrm{hr}$ per day to $24 \mathrm{hr}$ per day derives an air concentration of $50 \mathrm{mg} / \mathrm{m}^{3} \times 8 \mathrm{hr} / 24 \mathrm{hr}=17 \mathrm{mg} / \mathrm{m}^{3}$. This value is probably overprotective in that it is based on a chronic lifetime exposure of daily worker exposure. It may be under-protective, however, in not necessarily protecting for the subtle cellular level effects identified in the toxicological studies used to derive the RfC and MRL values.

Another option is to start from the mouse toxicological study that was used in the RfC and MRL derivations. The lowest effect level identified in the study was $9 \mathrm{mg} / \mathrm{m}^{3}$. If we divide by 10 to account for going from a low effect level to a no effect level, and then multiply by 10 to account from going from a chronic exposure to a subchronic exposure, we arrive at the original air Naphthalene concentration of $9 \mathrm{mg} / \mathrm{m}^{3}$. This value is a bout 2-fold lower (more protective) than the value derived above based on the OSHA value. This value was judged as protective for our specific remediation scenario by the ATSDR Emergency Response Duty Officer and their consulting medical toxicologist. Thus EPA Region 4 Technical Support Section recommends an air Naphthalene concentration of $9 \mathrm{mg} / \mathrm{m}^{3}$ as health protective for the specific short term exposure scenario outlined in this memo." [9]

\subsection{Action Levels}

An Action Level is a contaminant concentration that triggers site response measures. For example, exceedances 
documented at the site perimeter or fence-line of the Action Levels required response actions including application of suppression techniques using foam or other engineering controls and/or by temporary work stoppage. TVOCs, benzene and RPM10 are the primary Action Levels that were monitored as triggers for site response during real-time monitoring although the other BTEX compounds were monitored in the event of a TVOCs exceedance. The TVOC 15-minute average concentration was an initial trigger to do additional monitoring at the monitoring station where the reading was measured (Table 1).

\subsection{Continuous Air Monitoring}

Real-time air monitoring was conducted 24 hours per day seven days a week during active construction periods using the patented Air Logics Perimeter Air Monitoring System. The perimeter Air Monitoring System consisted of ten AMS, one meteorological tower, and one central computing system [2] [5] [6]. The aim of the realtime monitoring program was early detection of short-term emissions and off-site migration of site-related TVOCs and respirable dust. Each station was equipped with a Photovac Voyager portable field gas chromatograph (GC), capable of total hydrocarbon (THC) analysis, automated collection of constituent-specific data (benzene) when the Action Level was exceeded, and data logging [5]-[7].

Each particulate meter was equipped with a PM10 filter to monitor particulates less than 10 microns (PM10). Each photoionization detector (PID) and GC collected and analyzed samples, and sent results to the central computer system every two minutes [5]-[7]. All TVOC, individual VOC constituents, PM10 and meteorological data were stored in data loggers located within each monitoring station, sent in real-time via radio telemetry to the central computer system for monitoring and analysis [10] [11]. Each AMS had solar panels in case of electricity outage. If an alert for TVOC or PM10 occurred either during operating hours or after hours, site managers were notified via phone paging system. The pager module informed the air monitoring technician when a measured concentration was greater than the Action Levels (Table 2) [10] [11].

\section{Results}

\subsection{Pre-Remedial Action Air Monitoring}

Real-time fixed air monitoring for TVOC and PM10 conducted for pre-remedial action found only one increased

Table 1. Action levels and accepted ambient concentrations [3] [4].

\begin{tabular}{|c|c|c|c|}
\hline \multirow{2}{*}{ Parameter } & \multirow{2}{*}{$\begin{array}{l}\text { Short Term Action Level } \\
\text { (ppbv) }\end{array}$} & \multicolumn{2}{|c|}{ Site-Specific AAC } \\
\hline & & $\left(\mu \mathrm{g} / \mathrm{m}^{3}\right)$ & (ppbv) \\
\hline Total VOCs & 500 & - & - \\
\hline Benzene & 500 & 897 & 281 \\
\hline Toluene & 1326 & 5000 & 1326 \\
\hline Ethylbenzene & 1000 & 1000 & 230 \\
\hline Xylenes & 2000 & 100 & 23 \\
\hline Benz[a]anthracene & - & 64 & 6.8 \\
\hline Benzo[a]pyrene & - & 6 & 0.6 \\
\hline Benzo[b]fluoranthene & - & 64 & 6.2 \\
\hline Benzo[k]fluoranthene & - & 64 & 6.2 \\
\hline Chrysene & - & 636 & 68.1 \\
\hline Dibenz[a,h]anthracene & - & 6 & 0.5 \\
\hline Indeno[1,2,3-cd]pyrene & - & 64 & 6.2 \\
\hline Naphthalene & - & 9000 & 1700 \\
\hline PM10 & $150 \mu \mathrm{g} / \mathrm{m}^{3}$ & 150 & - \\
\hline
\end{tabular}

[1] The PM10 short-term action level of $150 \mu \mathrm{g} / \mathrm{m}^{3}$ is protective of potential exposures to PAHs and metals including arsenic and lead in dust. 
Table 2. Time-weighted 24 hour average ambient air samples [3] [4].

\begin{tabular}{|c|c|c|c|c|c|c|}
\hline Analyte & AACs & $\begin{array}{c}\text { Samples } \\
\text { Available }\end{array}$ & $\begin{array}{l}\text { Number of } \\
\text { Detections }\end{array}$ & $\begin{array}{l}\text { Minimum } \\
\text { Detected } \\
\text { Concentration }\end{array}$ & $\begin{array}{l}\text { Maximum Detected } \\
\text { Concentration }\end{array}$ & $\begin{array}{l}\text { Frequency } \\
\text { Exceeding } \\
\text { AAC }\end{array}$ \\
\hline \multicolumn{7}{|c|}{ Volatile Organic Compounds $\left(\mu \mathrm{g} / \mathrm{m}^{3}\right)$} \\
\hline Benzene & 897 & 269 & 6 & 2.7 & 4.9 & $0 / 269$ \\
\hline Toluene & 5000 & 269 & 68 & 2.6 & 10 & $0 / 269$ \\
\hline Ethylbenzene & 1000 & 269 & 3 & 3.6 & 4.3 & $0 / 269$ \\
\hline m,p-Xylene & 100 & 269 & 10 & 3.7 & 8.8 & $0 / 269$ \\
\hline o-Xylene & 100 & 269 & 1 & 6.4 & 6.4 & $0 / 269$ \\
\hline \multicolumn{7}{|c|}{ Polycyclic Aromatic Hydrocarbons ( $\left.\mu \mathrm{g} / \mathrm{m}^{3}\right)$} \\
\hline Acenaphthene & 150 & 266 & 216 & 0.0030 & 0.93 & $0 / 266$ \\
\hline Acenaphthylene & 150 & 266 & 105 & 0.0029 & 0.098 & $0 / 266$ \\
\hline Anthracene & 150 & 266 & 94 & 0.0032 & 0.13 & $0 / 266$ \\
\hline Fluoranthene & 150 & 266 & 131 & 0.0029 & 0.074 & $0 / 266$ \\
\hline Fluorene & 150 & 266 & 219 & 0.0025 & 0.55 & $0 / 266$ \\
\hline Naphthalene & 9000 & 266 & 265 & 0.0028 & 5.8 & $0 / 266$ \\
\hline Phenanthrene & 150 & 266 & 249 & 0.0030 & 0.83 & $0 / 266$ \\
\hline Pyrene & 150 & 266 & 111 & 0.0030 & 0.093 & $0 / 266$ \\
\hline Benz[a]anthracene & 64 & 266 & 0 & - & - & $0 / 266$ \\
\hline Benzo[a]pyrene & 6 & 266 & 0 & - & - & $0 / 266$ \\
\hline Benzo[b]fluoranthene & 64 & 266 & 0 & - & - & $0 / 266$ \\
\hline Benzo[g,h,i]perylene & - & 266 & 0 & - & - & - \\
\hline Benzo[k]fluoranthene & 64 & 266 & 0 & - & - & $0 / 266$ \\
\hline Chrysene & 636 & 266 & 0 & - & - & $0 / 266$ \\
\hline Dibenz[a,h]anthracene & 6 & 266 & 0 & - & - & $0 / 266$ \\
\hline Indeno[1,2,3-cd]pyrene & 64 & 266 & 0 & - & - & $0 / 266$ \\
\hline
\end{tabular}

level of PM10 on December 10, 2009 of $209 \mu \mathrm{g} / \mathrm{m}^{3}$, which was upwind of the site and was attributed to off-site activities. Of the 16 upwind, downwind and adjacent receptor TO-15 ambient air verification samples there were only four chemicals detected in the samples: toluene, acetone, 2-butanone, and methylene chloride. Only toluene is relevant to MGP-sites; this sample, collected December 11, 2009 was $3.8 \mu \mathrm{g} / \mathrm{m}^{3}$, which is below the AAC of $5000 \mu \mathrm{g} / \mathrm{m}^{3}$. As well, this sample was collected upwind and not considered related to the site. Other contaminates were not site related. Of the 15 upwind, downwind, and adjacent receptor TO-13A samples, the chemicals that were detected were naphthalene $\left(0.0028-0.010 \mu \mathrm{g} / \mathrm{m}^{3}\right)$, acenapthene $\left(0.0040-0.16 \mu \mathrm{g} / \mathrm{m}^{3}\right)$, and phenanthrene $\left(0.0032-0.0097 \mu \mathrm{g} / \mathrm{m}^{3}\right)$. None of these PAHs were above the AACs of $9000 \mu \mathrm{g} / \mathrm{m}^{3}$ for naphthalene, and $150 \mu \mathrm{g} / \mathrm{m}^{3}$ for acenapthene and phenanthrene.

\subsection{Continuous Air Monitoring}

For TVOCs, a total of 3517 samples were collected by the 10 AMS over the period of the project; out of these samples during the period from December 2009 to January 2011 the action level of 500 ppbv was exceeded on 42 days. Upon exceeding the level, the Photovac Voyager GC performed speciation for benzene and it was not detected during the project period. For PM10, a total of 3687 samples were collected at the 10 AMS during the project, and the action level of $150 \mu \mathrm{g} / \mathrm{m}^{3}$ was exceeded on 107 days during the project period. The 15 minute 
average concentrations of PM10 were measured at AMS 2 (above $113 \mu \mathrm{g} / \mathrm{m}^{3}$ ) and AMS 3 (above $150 \mu \mathrm{g} / \mathrm{m}^{3}$ ) on several occasions during remediation activities. For all of these occasions PM10 concentrations dropped below alert levels during the second 15-minute time period. These detections were attributable to either off-site activities or from on-site exhaust, generator exhaust, silo dust, or on-site vehicle traffic at the project site.

\section{Conclusion}

In this investigation, PM10 was measured above the Action Level at times due to diesel engine exhaust, vehicle traffic, off-site activities, or rain effects on the particulate monitors. Particulate matter was measured above the Action Level during the night or on weekends, or was detected upwind of remedial operations. These events were a result of off-site activities or weather conditions. The Air Monitoring Program and mitigation controls were effective at controlling potential Total Volatile Organic Chemicals and PM10 emissions from the MGP site through swift notification of action level exceedance. The AMP and the response by on-site personnel provided an early warning and control system to prevent and/or mitigate off-site exposures to site-related contaminants associated with intrusive operations. Laboratory results of site-related contaminants were not detected above the Accepted Ambient Concentrations; therefore, site monitoring and control actions were protective of human health over the duration of the air monitoring plan implementation.

\section{Acknowledgements}

This study was supported in part by the Center for Occupational/Environmental Risk Analysis and Management, College of Public Health, University of South Florida, Tampa, Florida and GEI Consultants, Inc.

\section{References}

[1] Department of Health and Family Services, Wisconsin Bureau of Environmental and Occupational Health (2004) Health-Based Guidelines for Air Management, Public Participation, and Risk Communication during the Excavation of Former Manufactured Gas Plants.

[2] USEPA (2008) Remedial Design/Remedial Action Consent Decree for Operable Units 1, 2 and 3.

[3] Office of Environmental Health Hazard Assessment, California Environmental Protection Agency (2009).

[4] USEPA (2009) Integrated Risk Information System.

[5] NRT (2009) Final Design Report.

[6] NRT (2009) Construction Quality Assurance Plan.

[7] NRT (2009) Fugitive Emissions Mitigation Plan.

[8] USEPA (2009) Mid-Atlantic Risk Assessment Regional Screening Table. http://www.epa.gov/reg3hwmd/risk/human/rb-concentration_table/

[9] Site Repository, Sanford Gasification Plant, EPA ID: FLD984169193, Sanford, Seminole County, FL, NPL Status: Superfund Alternative Approach, North Branch Library, Sanford.

[10] USEPA (2000) Guidance for the Data Quality Objectives Process for Hazardous Waste Sites, EPA QA/G-4HW EPA/ 600/R-00/007.

[11] USEPA (2000) Guidance on Systematic Planning Using the Data Quality Objectives Process, EPAQA/G-4. 
Scientific Research Publishing (SCIRP) is one of the largest Open Access journal publishers. It is currently publishing more than 200 open access, online, peer-reviewed journals covering a wide range of academic disciplines. SCIRP serves the worldwide academic communities and contributes to the progress and application of science with its publication.

Other selected journals from SCIRP are listed as below. Submit your manuscript to us via either submit@scirp.org or Online Submission Portal.
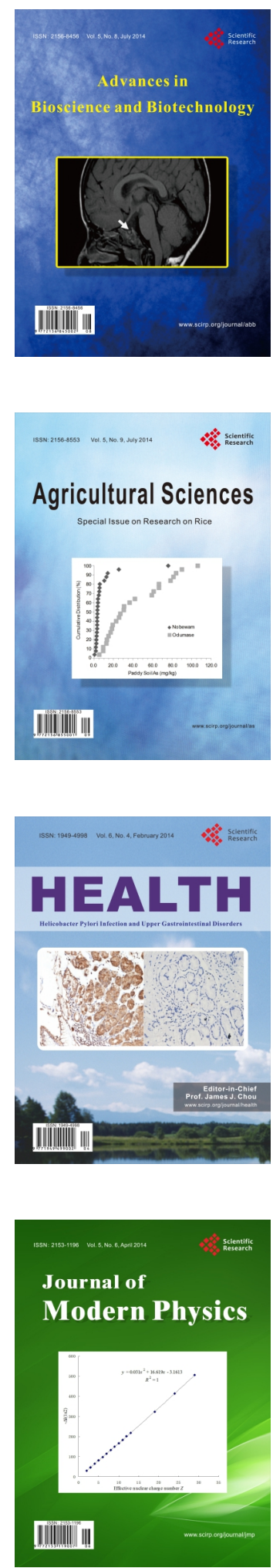
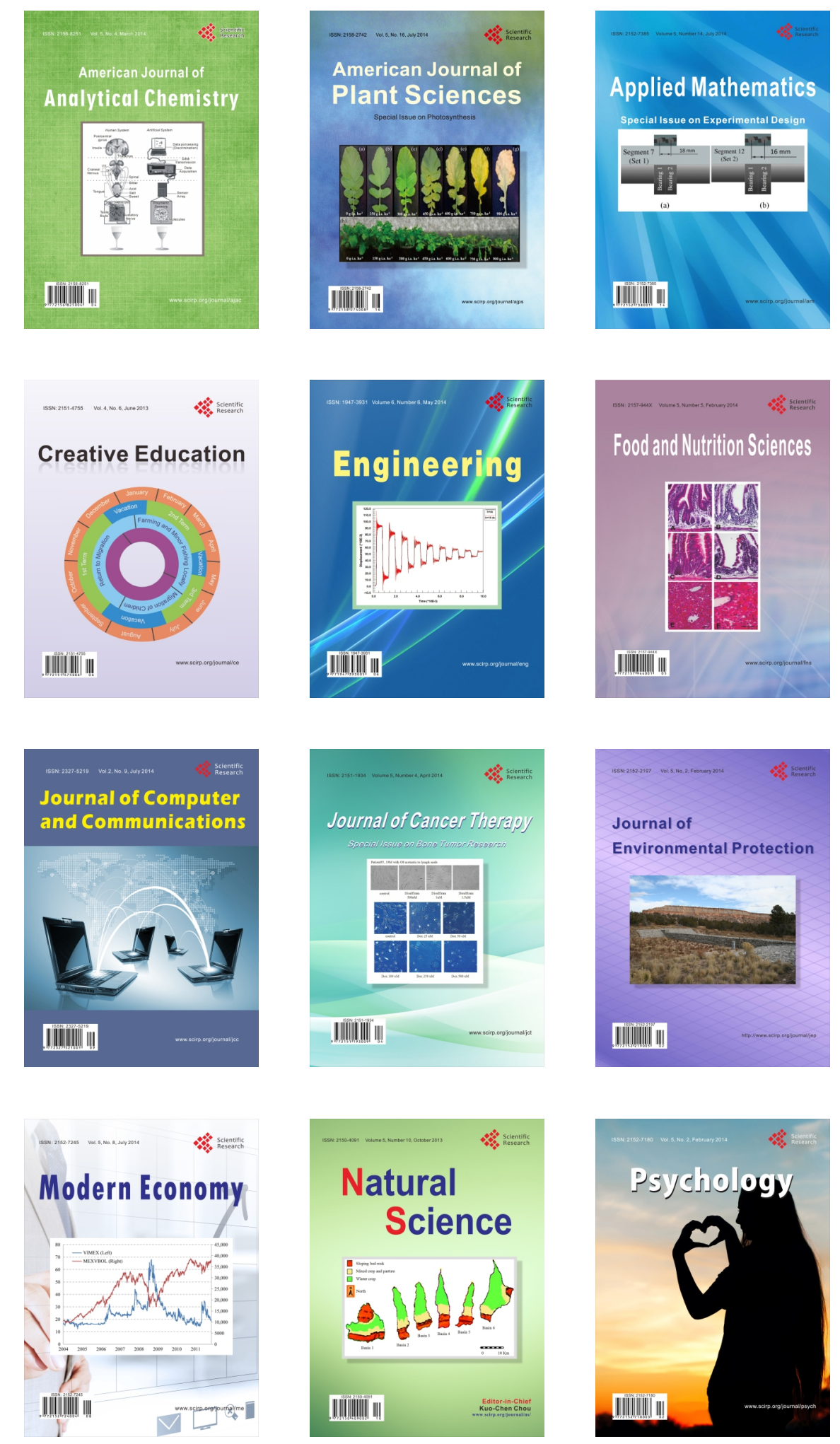